\begin{tabular}{|c|c|c|c|c|c|}
\hline \multirow{3}{*}{$\begin{array}{ll}\text { 2. ECN Category (mark one) } \\
\text { Supplomental } \\
\text { Direct Reviaton } \\
\text { Change ECN } \\
\text { Temponry } \\
\text { standby } \\
\text { superwedure } \\
\text { Caneow }\end{array}$} & \multicolumn{2}{|c|}{$\begin{array}{l}\text { 3. Originator's Name, Organization, MSIN, and Tolophone No. } \\
\text { David Tedeschi E6-15, 372-1485 }\end{array}$} & & $\begin{array}{l}\text { 4. USQ Required? } \\
\text { O Yos O No }\end{array}$ & \multirow{2}{*}{$\begin{array}{l}\text { 5. Dato } \\
\text { May 16, } 2000 \\
\text { 8. Approval Designator } \\
\text { N/A } \\
\end{array}$} \\
\hline & \multicolumn{2}{|c|}{$\begin{array}{l}\text { 6. Project Title/No.MWork Order No. } \\
\text { Fuel Retieval system /SNF }\end{array}$} & \multicolumn{2}{|c|}{$\begin{array}{l}\text { 7. Bldg/Sys./Fac. No. } \\
105 \mathrm{KE} / 105 \mathrm{KW} / 70.1\end{array}$} & \\
\hline & \multicolumn{2}{|c|}{$\begin{array}{l}\text { 8. Document Numbere Chenged by thls ECN (includes } \\
\text { sheot no. and rev.) } \\
\text { HNE-3526 rev } 2\end{array}$} & \multicolumn{2}{|c|}{$\begin{array}{l}\text { 10. Rolatod ECN No(o). } \\
\text { N/A }\end{array}$} & $\begin{array}{l}\text { 11. Related PO No. } \\
\text { N/A }\end{array}$ \\
\hline $\begin{array}{l}\text { 12a. Modincation Work } \\
\text { O Yea (nil out Bik. 12b) } \\
\text { No (NA Blks. 12b, } \\
\text { 12c, 12d) }\end{array}$ & $\begin{array}{l}\text { 12b. Work Packago No. } \\
\text { N/A }\end{array}$ & $\begin{array}{l}\text { 12c. Modification Work Cor } \\
\text { N/A } \\
\text { Dosign Authority/Cogg, En }\end{array}$ & oer Signature \& & $\begin{array}{l}\text { 12d. Reptored } \\
\text { or Standio } \\
\frac{N / A}{\text { Decion Autho }}\end{array}$ & 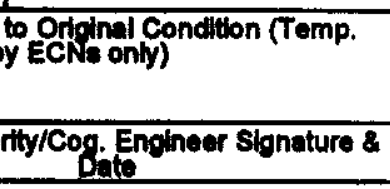 \\
\hline $\begin{array}{l}\text { 13a. Dascription of Change } \\
\text { This ECN revises } \\
\text { HNE-3526 from rev } \\
\text { The following chat } \\
\text { 1) Discussed eval } \\
\text { 2) Added in pictu } \\
\text { 3) Added in ATP f }\end{array}$ & $\begin{array}{l}\text { esign Package } \\
\text { to rev 3: }\end{array}$ & $\begin{array}{l}\text { b. Dosign Basolino Doc } \\
\text { Fuel Retrieval }\end{array}$ & $\begin{array}{l}\text { Oros } \\
\text { em Fuel }\end{array}$ & 10 & ol \\
\hline
\end{tabular}

14a. Juthon (mark on)

Crivita Chino

Deicon improvememt

Envionmental

Facimy Desativation

Arfound

Fitilinit conet.

Conct Enortominion

Devion Enoflombinion

\section{Junlication Dotalle}

$\mathrm{O}$ These additions will keep all the design life information assembled into One package. This package has been assigned an approval designator of N/A per HNF-PRO-233.

0

0 Us a categorial Exclusion, AP-NS-001-14 Arpandir $C$ Itemk.

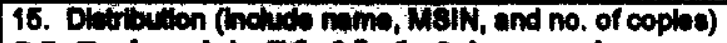

DJ Tedesch1 B6-15 1 Advanced

PA Young $\times 3-88 \quad 1$

GE Stegen $x 3-76 \quad 1$

TA Deluccht I6-38 1

DR Jackson K5-22 1

Central Files B1-07 1

RL Reading Rm. H2-53 1

FRS Working Files X3-88 1

KBasin Project Files X3-85

$\begin{array}{lll}\text { JM Henderson } & \text { G6-87 } & 1 \\ \text { JA Dent } & \times 3-65 & 1 \\ \text { JC Tucker } & \text { K5-22 } & 1 \\ \text { SD Godfrey } & \times 3-88 & 1\end{array}$

SD Godfrey X3-88 1

1 


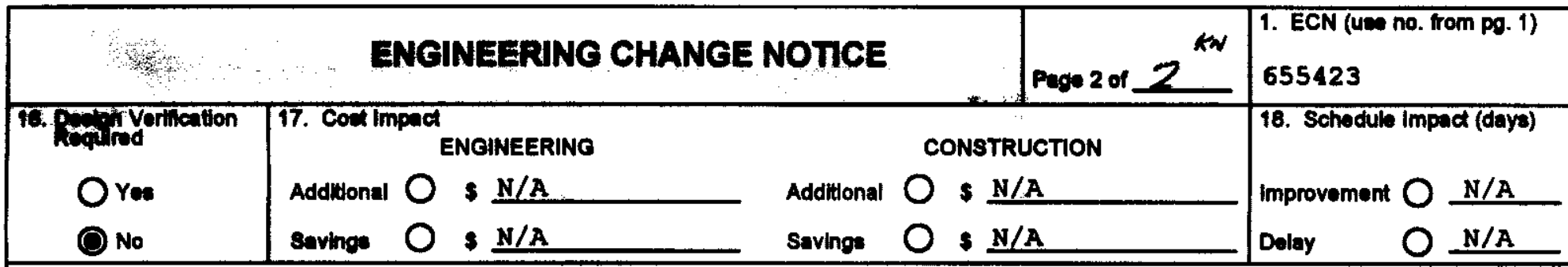

18. Change Imped Roview: Indleate the related documente (other than the engineering documente ldenthiad on Side 1) that will be afrected by the change described in Block 13. Enter the afiected document number in Block 20.

\begin{tabular}{|c|c|}
\hline SODOD & Selemic/Stress Analyals \\
\hline Funclental Design Crkeria & Strese/Design Report \\
\hline Oporathe specification & Intertace Control Drawing \\
\hline Critionity spacilication & Colibration Procedure \\
\hline Concespual Design Report & Inatallation Procedure \\
\hline Equipment spec. & Maintenance Procadure \\
\hline Cond. Epoo. & Englneering Procedure \\
\hline Procurement Spec. & Oporating Inatruction \\
\hline Vender information & Opernting Procedure \\
\hline Ou Manual & Opontionat sutety Requirement \\
\hline FsAprak & IEFD Drawing \\
\hline Safity Equlpment Lat & Cell Arrangement Drawing \\
\hline Radhition Work Pormit & Eccential Matorial specification \\
\hline Environmontal impect Statement & Fac. Proc. Samp. Schodula \\
\hline Environmontal Report & Inepecton Plan \\
\hline Environmantal Pormil & Imventory Adjutment Requed \\
\hline
\end{tabular}

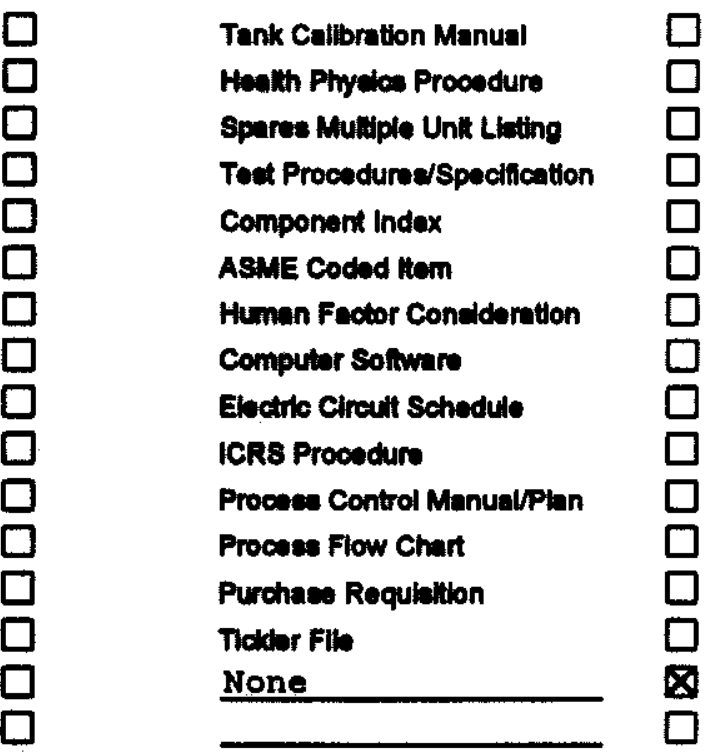

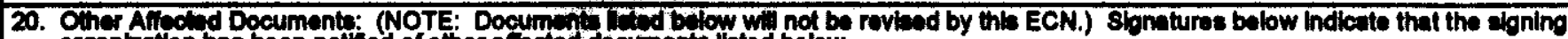
organtzation has been notined of other afiscted dockimente liated below.

Document Number/Reviaion

Document NumberiRovision

Document Number/Revision

None

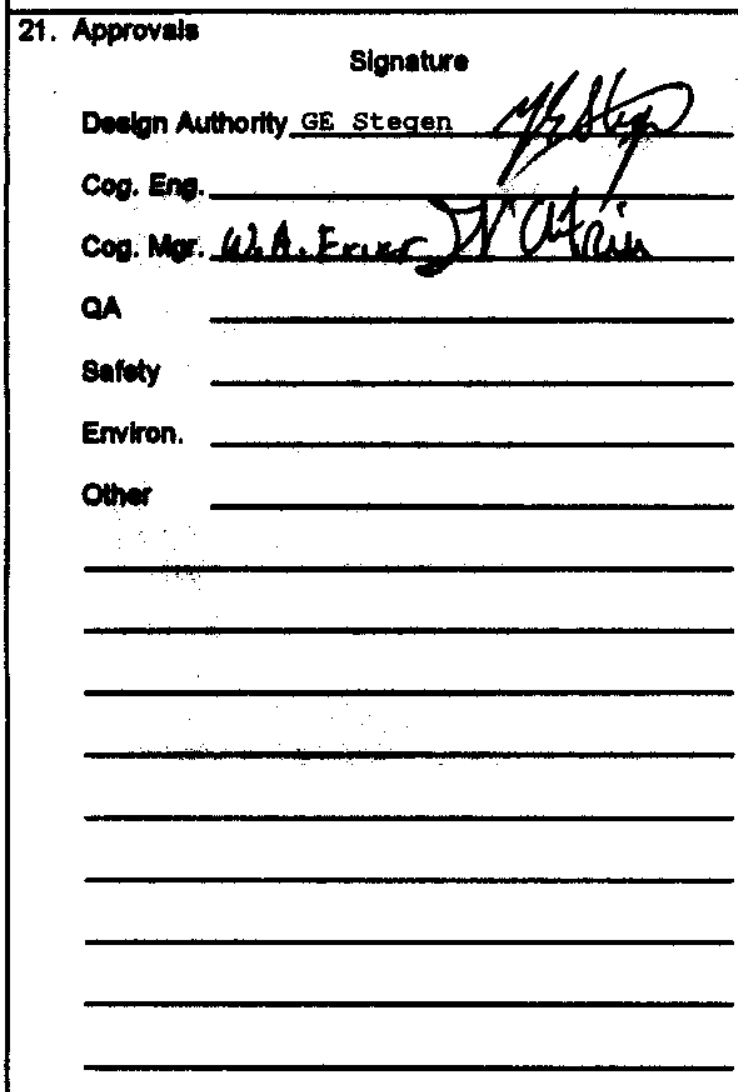

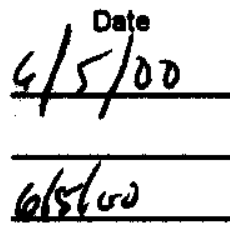

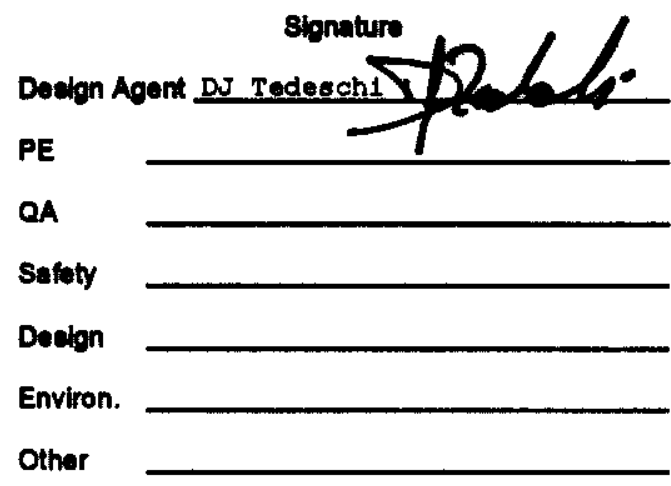

DEPARTMENT OE ENERGY

Signature or a Control Number that tracks the Approval Signature

ADPITIONAL

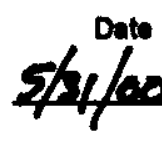

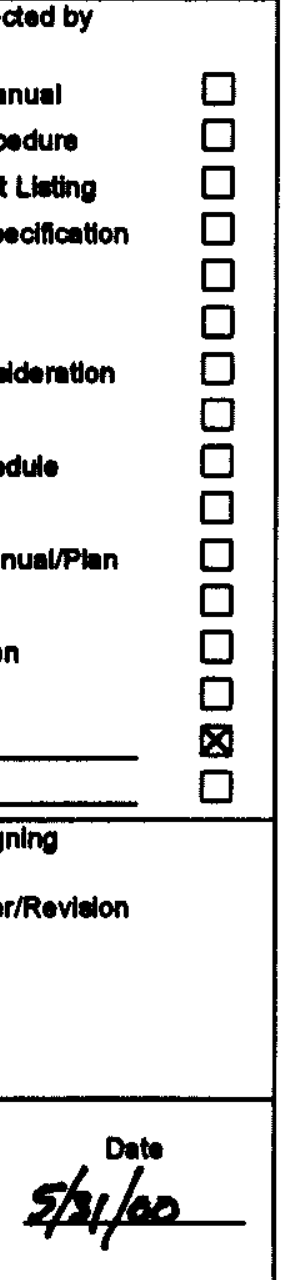


$\rho$

HNF-3526

Revision 3

\section{Design Package for Fuel Retrieval System Fuel Handling Tool Modification}

Prepared for the U.S. Department of Energy

Assistant Secretary for Environmental Management

Project Hanford Management Contractor for the

U.S. Department of Energy under Contract DE-AC06-96RL13200

Fluor Hanfora

P.O. Box 1000

Richland, Washington 
HNF-3526

Revision 3

ECN 655423

\section{Design Package for Fuel Retrieval System Fuel Handling Tool Modification}

Document Type: TR

Division: SNF

D. J. Tedeschi

Fluor Federal Services

Date Published

June 2000

Prepared for the U.S. Department of Energy

Assistant Secretary for Environmental Management

Project Hanford Management Contractor for the

U.S. Department of Energy under Contract DE-AC06-96RL13200

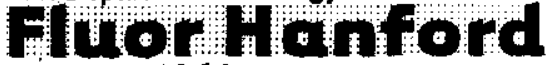

P.O. Box 1000

Richland, Washington

Hanen Mond Rélease Approval

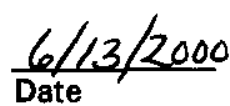


TRADEMARK DISCLAMMER

Reference herein to any specific commercial product, process, or service by trade name, trademark, manufacturer, or

otherwise, does not necessarlly constitute or imply its

endorsement, recommendation, or favoring by the United

States Government or any agency thereof or its contractors or subcontractors.

This report has been reproduced from the best avallable copy.

Printed in the United States of Amorican

Total Pages: $31 \leqslant N$ 


\section{recond of ravaron}

(i) 6 monim

घar -3526

Ging

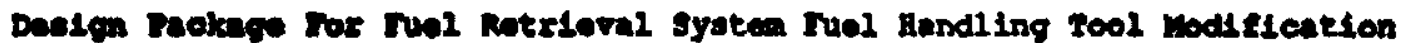

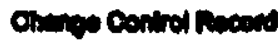

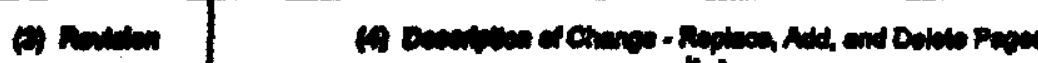

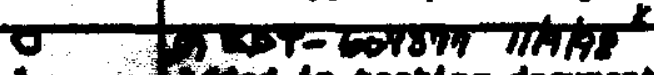

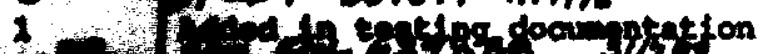

21. If

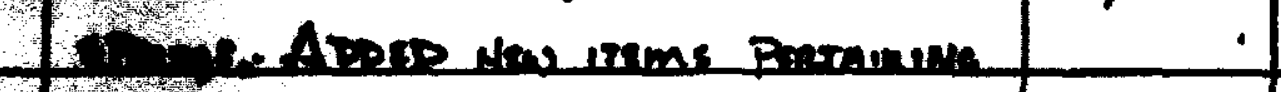

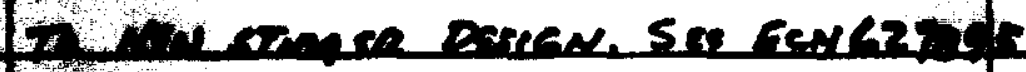

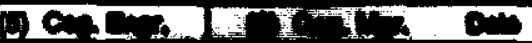

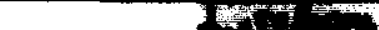

$\operatorname{Ln}$

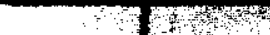

his mase great?

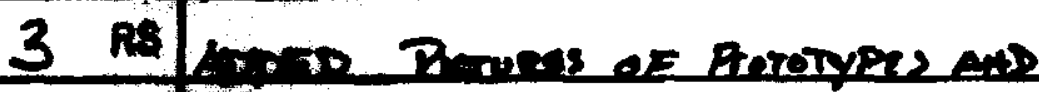

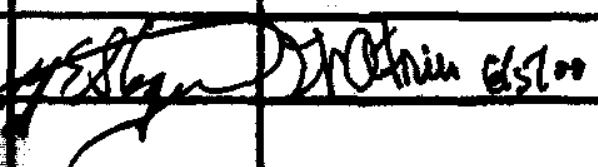

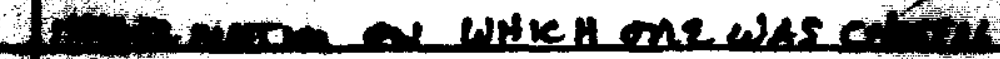

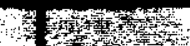

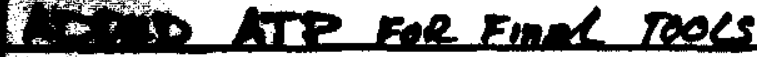

\begin{tabular}{|c|c|c|}
\hline & \\
\hline
\end{tabular}




\section{Design Package \\ for}

\section{Fuel Retrieval System Fuel Handling Tool Modification}

HNF-3526 Rev 3

May 16,2000

By David Tedeschi
of

Fluor Federal Services

1200 Jadwin

Richland, WA 99352

For Spent Nuclear Fuel Project, Fuel Retrieval System Sub-Project in

Fluor Hanford Inc.

P.O. Box 1000

Richland, WA 99352 


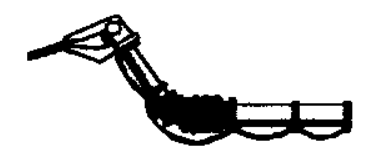

\section{Design Package for Fuel Retrieval System Fuel Handling Tool Modification}

May 16, 2000

HNF-3526 Rev. 3

Page 2

\subsection{Introduction}

The Fuel Retrieval System (FRS) Subproject at Hanford's $100 \mathrm{~K}$ basins Spent Nuclear Fuel Project has employed robotic arms (named Konan) to load fuel elements into long term storage baskets.

One Konan uses a fuel handling tool ("stinger tool") to load outer fuel elements into the fuel baskets. The stinger is inserted inside an outer fuel element after the element is placed vertically in a go-no-go gage, used to determine if the fuel can be loaded into an MCO basket socket. The Schilling supplied stinger operates by expanding an elastomer spring inside the outer fuel element. The spring is actuated in its expanded mode when the Konan jaws are opened. The spring's expansion exerts enough force against the inner diameter of the element's wall that it can be lifted.

Use of the Schilling stinger tool in FRS testing and training proved to be inadequate for the expected throughput requirements. This design package provides a new stinger design that will meet requirements listed in this document. The new design will incorporate Schilling's design for attaching the stinger to the Konan.

\subsection{Scope}

\subsection{Objectives}

This dealgn package documents design, fabrication, and testing of new stinger tool design. Future revisions will document further development of the stinger tool and incorporate various developmental stages, and final test results.

\subsection{Products Delivered}

Results from this package will deliver the following:

Documents

a) Functions and requirements, analysis, graphical depictions, test specifications, test procedures, and final test reports

b) Hanford formatted drawings and $\mathrm{ECN} /$ modifications to vendor information files 


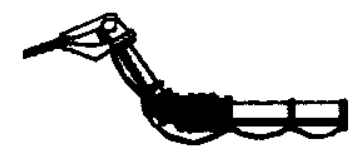

Design Package for Fuel Retrieval System Fuel Handling Tool Modification

May 16, 2000

HNF-3526 Rev. 3

Page 3

c) Acceptance test requirements for production units

d) Vendor information

Hardware

a) Prototype stinger tool

b) Final stinger tool

\subsection{Brief Description of Problem}

The actuation mechanism of the stinger provided by Schilling, is prematurely failing due to loads it endures under normal basket loading conditions. High concentrated stresses exceed the yield strength of the actuation mechanism, which causes deformation and eventual failure. The actuation mechanism is a push-pull cable type device. It consists of a wire rope sliding through a wire-braided sleeve. When the Konan jaws are opened, a lever arm attached to the sleeve pushes the sleeve over the wire rope. The sleeve applies a compressive force to the urethane spring that causes the spring to expand. The elastomer spring expansion applies a force against the inner wall of the fuel element, which enables the fuel element to be lifted. A fuel element will be lifted, as long as the frictional forces between the wall of the element and the elastomer spring are not overcome by the weight of the fuel alement. See vendor information file CVI 50062, drawing number 1013737, by GEC Alsthrom, for graphical depiction of the Schilling stinger.

\subsection{Products Requirements and Constraints}

Gencurt design requirements/criteria for the Spent Nuclear Fuel Project Fuel Retriovil subproject are in HNF-S-0461, Specification For Design Of The SNF Proiect Fual Retrieval Subproject. The following additional requirements apply specifically to the stinger tool.

\subsection{Dimensional/Physical Constraints}

a) Stinger will pick up an outer fuel element that is placed in the vertical position but not be required to pick up an inner fuel element.

b) Length of the actuator mechanism is approximately $18+2,-0$. inches but will be determined by testing through successful loading of an dummy outer fuel element into an MCO basket.

c) Stinger end-effector must be able to accommodate the following dimensions:

Fuel Elements

- Outer fuel element maximum inside diameter: 1.779 inches. 


\section{Design Package for Fuel Retrieval System Fuel Handling Tool Modification}

May 16, 2000

HNF-3526 Rev. 3

Page 4

- Outer fuel element minimum inside diameter: 1.691 inches. (Dimensions taken from drawing number H-1-39775)

- Assume outer fuel element weighs approximately $35 \mathrm{lbs}$. in air. Reference HNF-SD-SNF-TI-009, rev. 2, 105-K Basin Material Design Basis Feed Description for Spent Nuclear Fuel Project Facilities.

Based on the above information, the design parameters are the following:

a) Stinger can pick up fuel elements weighing $35 \mathrm{lbs}$. (dry weight) with inside diameters ranging from 1.64 to 1.9 inches.

b) Stinger can pick up a fuel elements weighing $35 \mathrm{lbs}$. (dry weight) when its end-effector is inserted in the element a minimum of .25 inches.

\subsection{Environmental Constraints}

a) Stinger material must be able to withstand the effects of a high radiation field of $40 \mathrm{rem} / \mathrm{hr}$ for 90 days. This value is a conservative interpretation of BNFL Inc. Report L/B-SD-SNF-RPT-04, Radiological Shielding Design Plan for the SNF Fuel Retrieval Project.

b) Stinger shall be submersible in deionized water at a temperature of 50 ${ }^{\circ} \mathrm{F}$ for its design life.

\subsection{Operational Requirements}

a) Stinger should operate for a minimum period of 3 months assuming 3 shifts per day, 7 days a week, and process about 140 fuel assemblies per day. The stinger life expectancy should be 90 days, based on these assumptions.

b) Stinger shall be able to operate under 7-20 feet of water.

c) Stinger actuation design shall take into account the following possible forces induced on it in the various directions:

- A tensile force due to lifting the fuel element (approximately) $35 \mathrm{lbf}$ dry weight.

- A compressive force due to placement of element. Actual amount of force is unknown and may vary with the stinger design. However, an estimated maximum force is about 400 lbf. 


\section{Design Package for Fuel Retrieval System Fuel Handling Tool Modification}

May 16, 2000

- A lateral force due to inserting the stinger in the element, rotating the fuel basket, and placing an element inside the basket. Actual amount of force is unknown.

d) Stinger shall be able to be inserted in a fuel element and used to rotate the fuel basket.

e) Stinger tool shall be flexible enough to hang plumb when being inserted into an element and when trying to insert an element into a fuel basket. The design needs to accommodate a free motion of the block \pm 6 inches in a hemispherical direction.

f) Stinger shall not cause damage to the camera or hinder wrist movement when wrist rotates. Upon wrist rotation, it is desired that the stinger hangs with a tip to toe distance of 1 foot.

g) Stinger will not be used to pull fuel from a canister.

h) Stinger should account for potential snags that could produce a load of $350 \mathrm{lbf}$ in tension. (This reemphasizes requirement $4.3 \mathrm{C}$ ).

\subsection{Maintenance Requirements}

a) Stingers will be thrown away unless there is an inexpensive method for replacing failed parts.

b) The Schilling supplied stinger block that attaches the stinger to the Konan arm shall be used as a part of any new design. The block has been designed for easy attachment and removal from the Konan and it has been accepted by Operations.

c) Stinger shall be fully retrievable if it fails when inside a fuel element. Note: This requirement was not incorporated in the value analysis evaluation of the design but was accounted for in the designs.

\subsection{Applicable Laws, Regulations, and Standards}

Applicable Fluor Daniel Hanford Engineering and SNF Project procedures shall be used for documenting development stages of design, reviews, and approvals of engineering documents. 


\subsection{Additional Objectives}

These objectives are to be considered when evaluating prototypes that meet all the requirements but need additional reasons for determining the best design.

- Fabrication cost

- Higher life expectancy

- Takes abuse well

- Handles better/minimal aligning required for deployment

- Minimal training required

- Operator preference

\subsection{Development of Product}

\subsection{Management of Task}

\subsubsection{Engineering}

Engineering will be done using a team made up of staff from Fluor Federal Services, Cogema, and Pacific Northwest National Laboratories. Documents will be approved by Fluor Hanford Inc. Fuel Retrieval System Design Authority(s).

\subsubsection{Procurement}

Developmental materials will be procured using credit cards from Numatec, Cogema, or Pacific Northwest Laboratories. Final parts will be ordered using appropriate Quality levels as directed by the Design Authority(s).

\subsubsection{Initial Project Fabrication and Construction}

Fhor Federal Services will be responsible for managing final fabrication and DynCorp or HAMTC personnel will be responsible for final construction. The FRS Project Manager will determine use of another contractor for managing the fabrication as required.

\subsubsection{Prototype}

Prototypes will be assembled using Fluor Federal Services, Cogema, and Pacific Northwest Laboratories. The Engineer in charge will maintain redline control of prototype fabrication drawings/sketches. Prototype testing and test results will be documented by the FRS test engineer. 


\subsection{Discussion of Development}

Operational testing of the Schilling stinger tool revealed that the tool had to be modified significantly for long-term use. See previous revisions of this document for a history on what was done to reach this determination.

The first modification made was a replacement of the large elastomer spring. Operational testing showed that the stinger tool needed to lift an outer element only and that the inner elements would be loaded with the jaws. This led to modifications accommodating outer elements exclusively. Based on engineering experiences with similar devices, it was decided to use an expanding collet rather than the elastomer spring. After prototype testing several collets with various materials, Inconel 718 gave the best results. It has a yield strength of $170 \mathrm{ksi}$ if heat treated, which proved to provide the collet with necessary spring properties.

The collet is a split tube with concentric internal angles on either side. The collet expands when two stainless steel conical end pieces, cut to the same angle as the collet, are forced into the collet. The dual pieces cause the collet to uniformly expand which helps prevent it from deforming if it is inserted only partialy into an element.

Operational testing also demonstrated us of the Schilling mounting block that connects the stinger to the Konan and its ease of removal. A separate tool was developed to remove the block and can be found on drawing H-183905, "K-Basin FRS Konan Manipulator Fuel Tool Extractor Device".

Observation of the failed Schilling tool and other prototypes showed that failure occurred primarily in the actuation mechanism that expands the collet. A team consisting of Operations, Engineering and Technicians were assembled to evaluate the problem. The team refined the stinger requirements (refinements have been incorporated in section 4.0) and brainstormed 7 solutions. Solutions can be found in Appendix F. The team decided that the final design should use the collet design with the Schilling mounting block and concentrate efforts on modifying the actuation method. Several solutions were brainstormed and then evaluated using a value analysis process.

A value analysis process ranks the criteria/requirements of the tool and evaluates them against each potential design (with what knowledge is known about the design). The designs are then ranked based on the highest score it receives. Analysis documentation including the Criteria Matrix, Evaluation Matrix, and the Criteria can be found in Appendix F. 
The value analysis showed the design most able to meet the requirements was the reverse acting design that has the collet normally expanded. The actuation mechanism is used to relieve the expansion when the jaws are opened. The second ranked design uses self-contained hydraulics as a means for actuation the collet. This design uses water as its hydraulic fluid. The third ranked design is a modification of the existing style with a cable inside a sheath for its actuation.

Fluor Federal Services(FFS), Cogema (COE), and Pacific Northwest National Labs (PNNL)each took one of the three designs and built a prototype for testing. PNNL's design modified the Schilling stinger, FFS design implemented a stinger using hydraulic actuation, and COE's design used a reverse actuation style. The PNNL tool was finished first and was tested on the Konan for the longest time. It was chosen by Operations to be used in the basin. See Section 5.3 for a discussion on how the tools were evaluated. See Appendix A for pictures of the designs.

Final designs were documented on drawings. The Hanford retrieval numbers for them are:

PNNL design H-1-84841

COE design $\quad \mathrm{H}-1-84843$

FFS design $\quad$ H-1-84839

\subsubsection{Sketches/Drawings}

All graphical depictions will be found in Appendix A. This Appendix contains the following:

- Sketch of test setup

- Pictures of designs and test setup

\subsection{Verification of Product Design}

Verification of the stinger modifications were done through prototype testing. The testing verified features/requirements listed in section 4 of this document. Upon satisfaction of a prototype, the design(s) will be documented using an $\mathrm{H}-1$ - series drawing and a final tool will be fabricated from a released drawing. Final design verification tests will be performed per the attached verification test specification and attached in Appendix D. Acceptance testing of fabricated stingers to be used in the basin will be done to confirm that the tool was fabricated correctly and that it still operates like the prototype stinger. This testing will be done before being used in the field. 
May 16, 2000

\subsubsection{Analysis}

\subsubsection{Calculations}

There were no calculations done.

\subsubsection{Testing}

Each design underwent testing as apart of its verification. This testing was to include a consistent evaluation, (as discussed in the previous revision). Due to lack of funding and time constraints, the evaluations consisted of minimal operation time on the Konan and placing the tools on cyclic machine. Consequently, the evaluation sheets were never filled out.

All three designs were placed on a cyclic machine that continually actuates the collet. Each design successfully underwent 50,000 plus cycles and still operated after testing was complete. During the test, the collet's diameter was measured in the fully actuated and nonactuated position. Minimal degrading was observed in any of the designs. The reverse actuation (COE's design,) did encounter significant wear issues but were overcome by a better choice of materials. The other two designs worked near almost flawlessly. Significant changes noted were documented in a logbook. Copies of the $\log$ are in Appendix C. See Appendix A for a sketch and pictures of the test setup.

Final fabrication of the stinger will be subjected to an Acceptance test. The test is attached in Appendix D. This test will verify that the tools were a fabricated correctly and will ensure any minor adjustments are made before releasing them into service.

\subsection{Turn Over of Product}

\subsection{Final Design Description}

The final design(s) were documented on separate drawings. See discussion for a list of the drawing numbers.

\subsection{References}

Radiological Shielding Design Plan for the SNF Fuel Retrieval Project. BNFL Inc. Report L/B-SD-SNF-RPT-04 
HNF-3526 Rev. 3

Page 10

105-K Basin Material Design Basis Feed Description for Spent Nuclear Fuel Project Facilities. HNF-SD-SNF-TI-009, rev. 2

Specification For Design Of The SNF Project Fuel Retrieval Subproject. HNF-S-0461

Final Report -Spent Nuclear Fuel Retrieval System Manipulator System Cold Validation Testing_. PNNL - 12135 


\section{Design Package for Fuel Retrieval System}

Fuel Handling Tool Modification

May 16, 2000

HNF-3526 Rev. 3

Page A-0

\section{Appendix A}

\section{Graphical Depictions of Product}




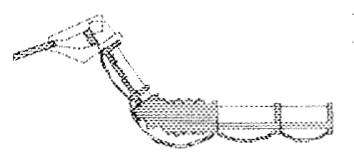

Design Package for Fuel Retrieval System Fuel Handling Tool Modification

$$
\text { May 16, } 2000
$$

HNF-3526 Rev. 3

Page A-1

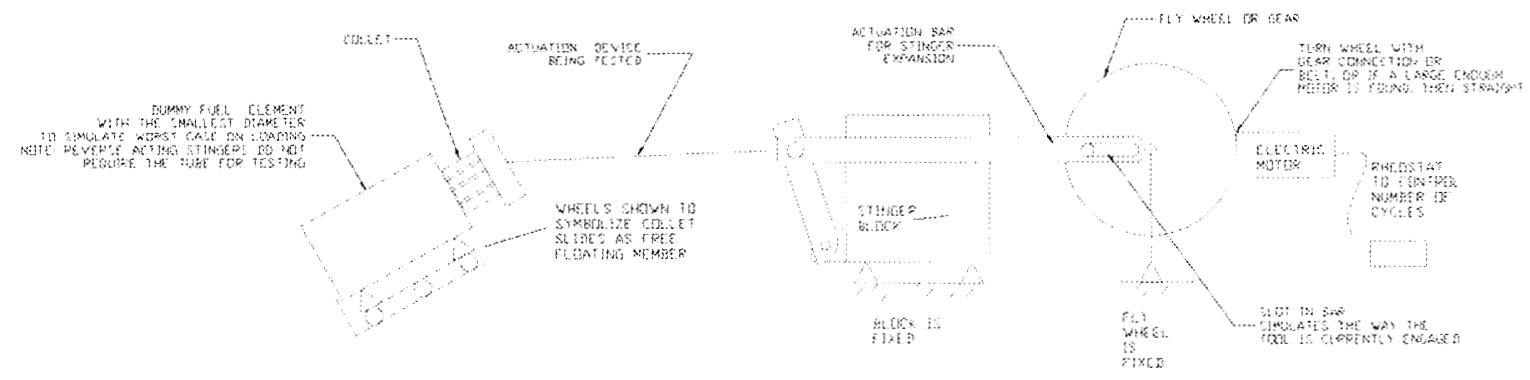

Sketch of Cyclic Machine used to test stinger collet actuation.

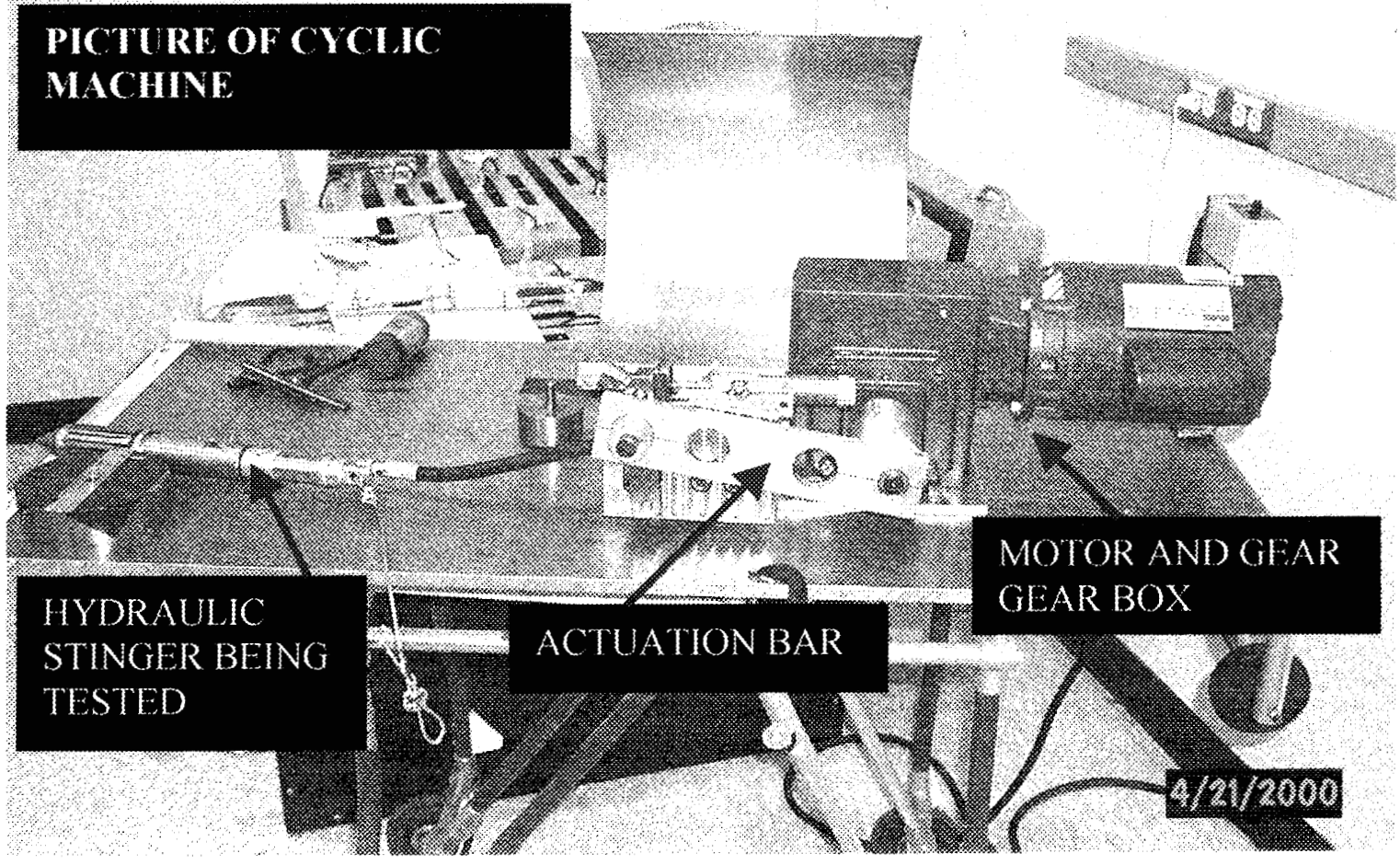




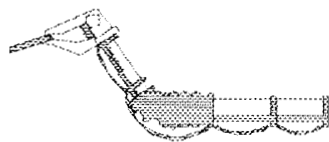

Design Package for Fuel Retrieval System Fuel Handling Tool Modification

May 16,2000

HNF-3526 Rev. 3

Page A-2

\section{DIRECT ACTING STINGER DESIGN - BY PACIFIC NORTHWEST} NATIONAL I ABORATORY

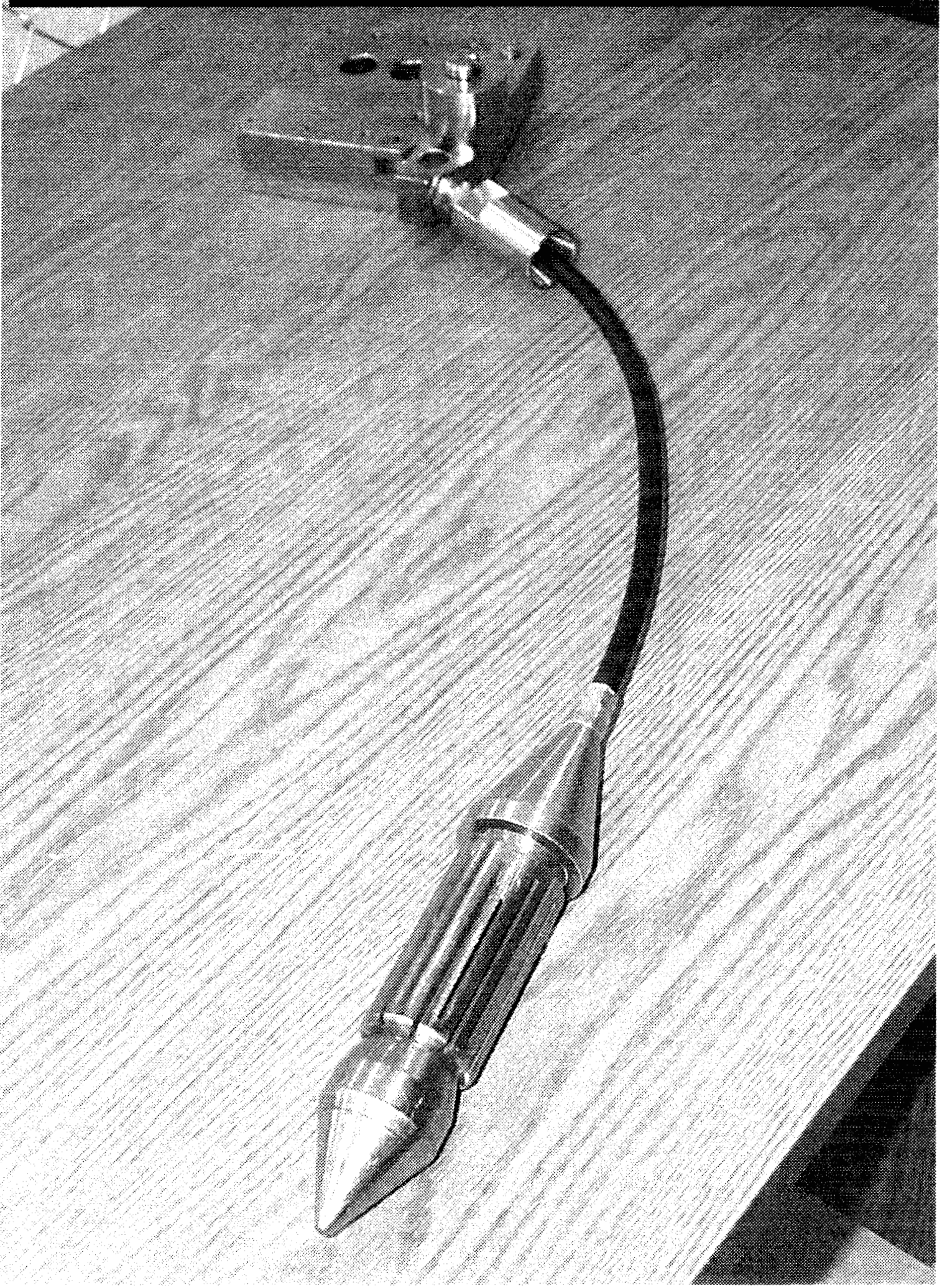




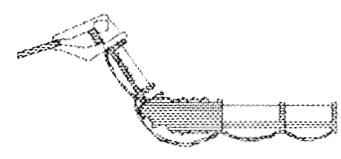

Design Package for Fuel Retrieval System Fuel Handling Tool Modification

May 16, 2000

HNF-3526 Rev. 3

Page A-3
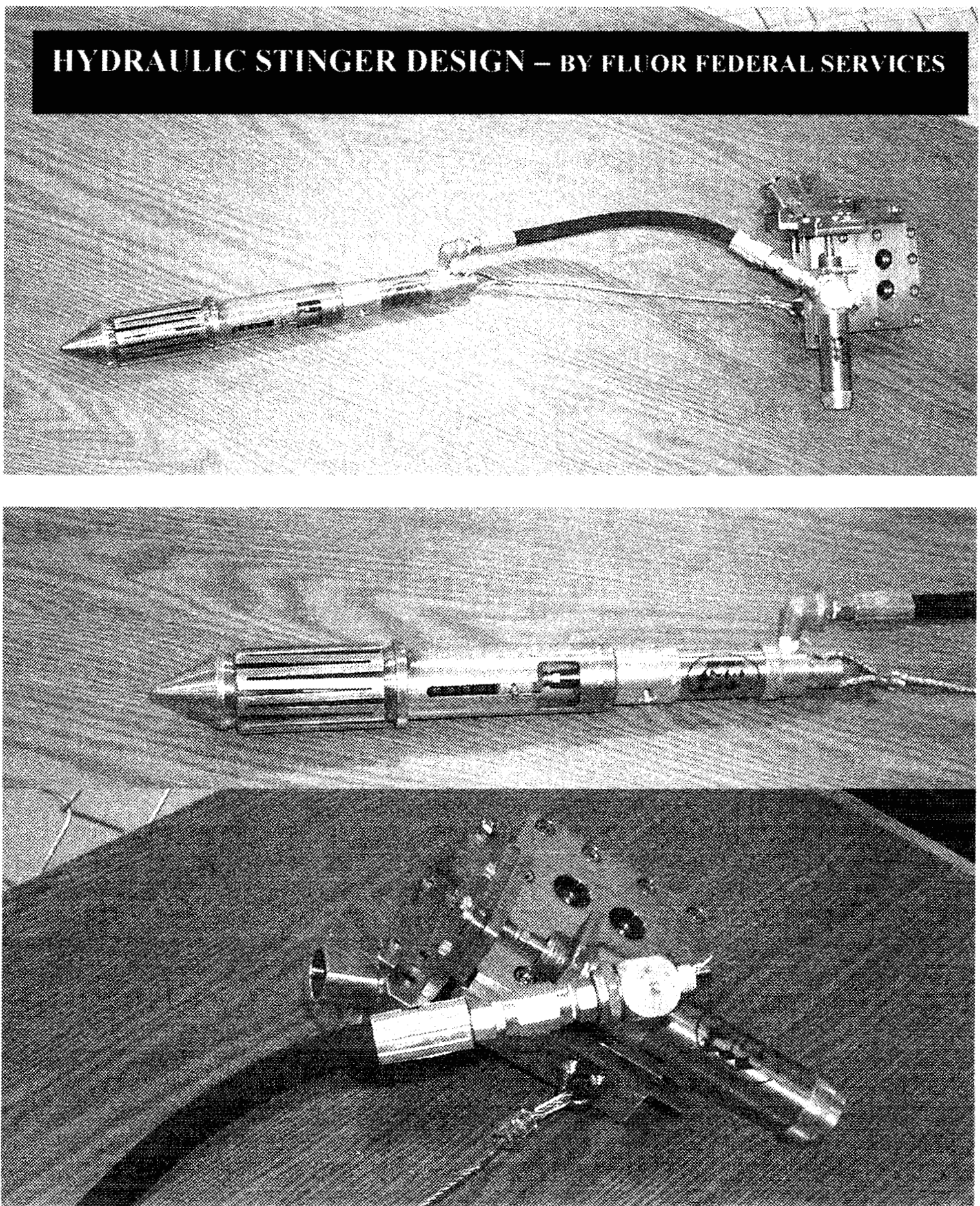


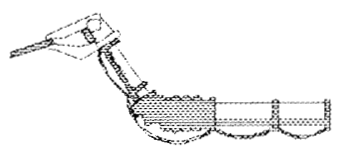

Design Package for Fuel Retrieval System Fuel Handling Tool Modification

May 16, 2000

HNF-3526 Rev. 3

Page A-4
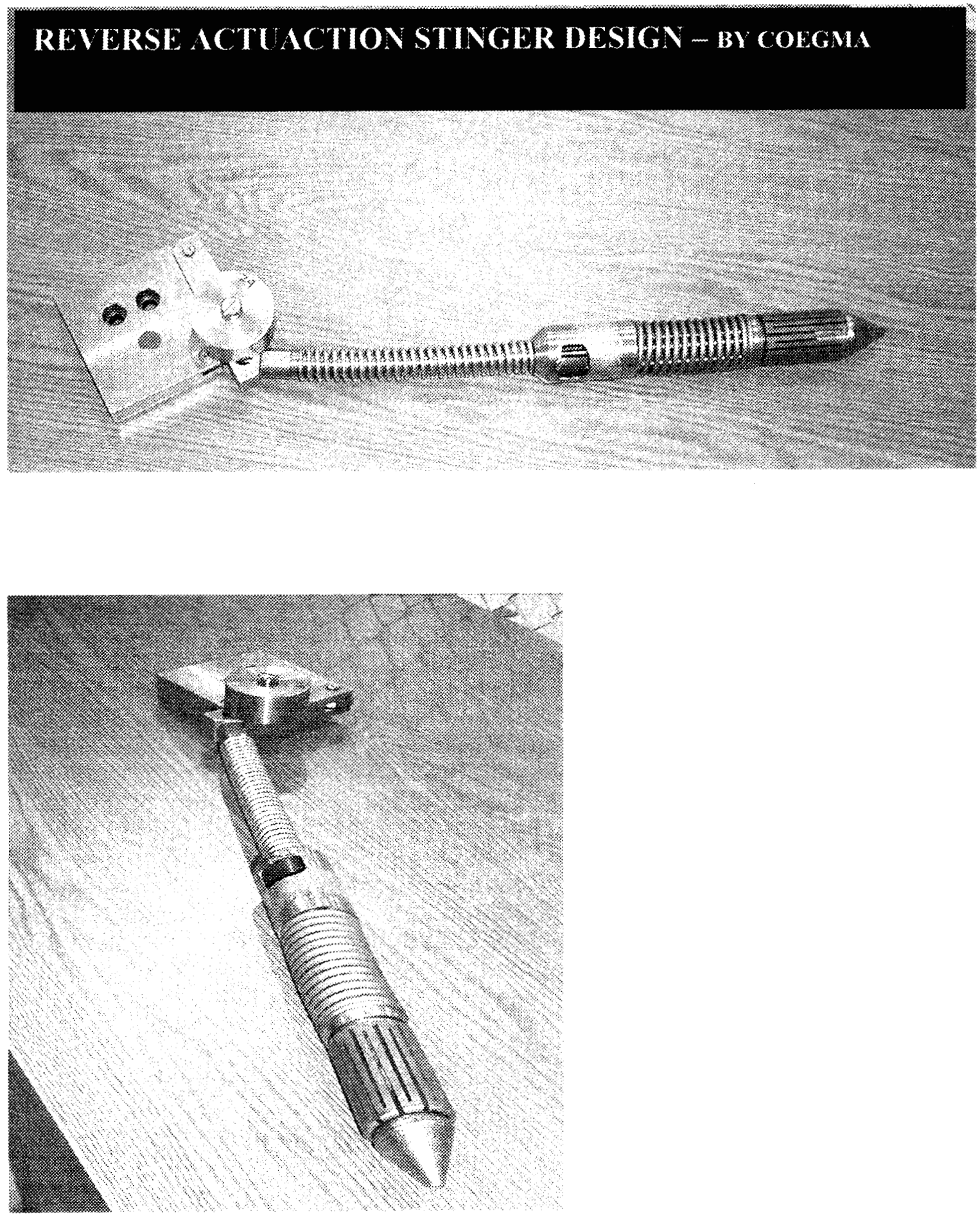
Design Package for Fuel Retrieval System Fuel Handling Tool Modification

May 16, 2000

HNF-3526 Rev. 3

Page B-0

Appendix B

Calculations

(See revision 1 for calculations) 
Appendix C

Test Specifications:

Prototype Test Matrix

Prototype Test Procedure

Prototype Test Evaluation Sheet

Testing Log Sheets 
SEE PREVIOUS REVISIONS FOR :

Prototype Test Matrix, Prototype Test Procedure, Prototype Test Evaluation Sheet 
HNF-3526 Rav 3

Page C-2

COGEMA DESIGN

\begin{tabular}{|c|c|c|c|c|c|c|}
\hline \multirow{3}{*}{ DATE } & TIME & INITIALS & condition & tot. hours & tot. cycles & observations \\
\hline & 1300 & $\operatorname{csm}$ & (start) & & & \\
\hline & 1400 & $\mathrm{csm}$ & 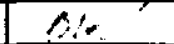 & 1 & 2700 & some poor haise \\
\hline & & & & & & 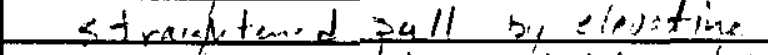 \\
\hline & & & & & & 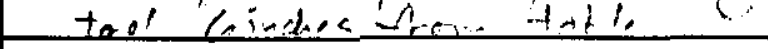 \\
\hline & 1500 & $\operatorname{csm}$ & $C E$ & 2 & 5400 & $35^{\circ} \mathrm{C}$ \\
\hline & fivos & $\operatorname{cim}$ & ok & 3 & 8100 & 36.2 \\
\hline & 1700 & $c_{m}$ & ak & 4 & $10, \$ \circ c$ & sc" (Shest Dawn) \\
\hline $4-6$ & 0800 & $\operatorname{com}$ & OL & cestart & & $2 t^{2} C$ (noticedoly quieter) \\
\hline & & & ok & & & $37^{\circ} \mathrm{C}$ ("growil" is back) \\
\hline & 0900 & Cem & $O E_{4}$ & -5 & 13,500 & (norid expeanding is \\
\hline & 1200 & $c-2=$ & ak & 6 & 16200 & $34^{\circ}$ cellet stlll work \\
\hline & & & & & , & (most of expe \\
\hline & & & & & & one areaf \\
\hline & $1 / 100$ & $c \sin$ & ikk & $\overline{7}$ & 8990 & $35^{5}$ \\
\hline & 1102 & csm & $\frac{x}{x}$ & $\frac{1}{7}$ & $\begin{array}{lll} & 0\end{array}$ & Eubie broke, srin \\
\hline & & & & & & 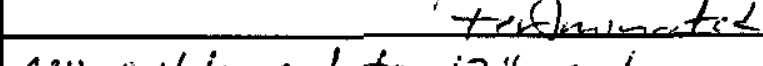 \\
\hline & & & & & & 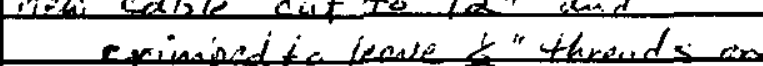 \\
\hline & & & & & & Qud " 1 "and in thls \\
\hline & & & & & & $\left\{\begin{array}{l}\left(L=143^{3 / 6}\right) \text { trumed to } 14 / 9 \\
(127)\end{array}\right.$ \\
\hline & & & & & & (Ppring of is \\
\hline $7-6$ & 1530 & $\frac{c 5 n}{2 m}$ & ok & restart & & \\
\hline & 1630 & & $0<$ & & 2700 & $33^{\circ} \mathrm{E}=\mathrm{N}_{\text {cise reduced }}$ \\
\hline$i-7$ & $7: 00$ & $\frac{-10}{1.31}$ & sk & $\frac{(\cos \theta \tan t)}{2}$ & & \\
\hline & 0900 & $\cos$ & ok & $\frac{2}{3}$ & 8100 & $34^{\circ}$ \\
\hline & $\therefore 0_{0}$ & Sim & $a k$ & $a$ & 10,820 & $3=3^{2}$ \\
\hline & $\frac{1100}{2200}$ & $s_{2}$ & 025 & 5 & 3,500 & 31 \\
\hline & $/ 346$ & $\frac{70}{\operatorname{csin}}$ & 100158 & $\frac{6}{7.5}$ & & $\overline{3 c 0}+2+20$ \\
\hline & & & 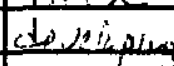 & & & Tiemp shut dewn \\
\hline & raves & $\mathrm{csm}$ & restoent & $\neq$ & & \\
\hline & 1.420 & & 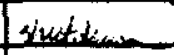 & 8.0 & 21,700 & P4 \\
\hline $24-10$ & $8: 45$ & 20 & ok & 90 & $2 d^{\prime 400}$ & Cud ded fan for moter conti \\
\hline & $\frac{9.45}{1045}$ & $\operatorname{css} x$ & tok & 9.81 & $\frac{24,400}{11,000}$ & $\frac{20^{\circ} \mathrm{C}}{250 \mathrm{C}}$ \\
\hline & 10.45 & cs & is & 1 & 28,700 & $\frac{28}{25 \cdot 8}$ \\
\hline & 246 & $\sin$ & ok & 12,0 & 32,400 & $29^{\circ} \mathrm{C}$ \\
\hline & $\sqrt{1345}$ & 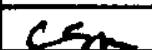 & $O K$ & 13,0 & 35.100 & $30^{\circ} \mathrm{C}$ \\
\hline & 1445 & $\operatorname{csm}$ & oft & 44.0 & 37,800 & $31^{\circ} C$ \\
\hline & 545 & $\cos n$ & $i k$ & 15,0 & 40,500 & Sinct down for $\mathrm{Din}$ \\
\hline & 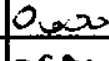 & 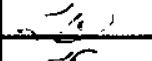 & & & 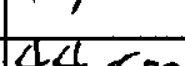 & \\
\hline & $\log x$ & 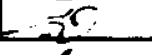 & ok & $\frac{17.00}{1800}$ & 144,500 & \\
\hline & $\begin{array}{l}0900 \\
1100\end{array}$ & 90 & ok & 2000 & $\begin{array}{l}46200 \\
\$ 1600\end{array}$ & \\
\hline
\end{tabular}




\section{FFS DESIGM}

\begin{tabular}{|c|c|c|c|c|c|c|}
\hline$\frac{\text { DATE }}{1.12 \pi x}$ & $\frac{\text { TIME }}{13,5}$ & $\frac{\mid \text { INTIALS }}{c^{\prime} m}$ & $\frac{\text { condition }}{(\text { stait) }}$ & \begin{tabular}{|l} 
tot. hours \\
$t^{2}$
\end{tabular} & $\frac{\text { tot. cycles }}{\theta}$ & \begin{tabular}{|c|c|} 
& observations \\
opens fo 1.83 \\
$3 s^{\circ} \mathrm{C}$
\end{tabular} \\
\hline & $\frac{1.15}{1.15}$ & $\frac{12}{6 m}$ & icosebed 11 & $i$ & 2100 & $25 \mathrm{c}^{\mathrm{c}}$, tightened dingle plate \\
\hline & 1515 & $\mathrm{cen}=$ & ok & 2 & $.540 c$ & \\
\hline & 1615 & $c_{n}$ & ok & 3 & & shuctdoin for pm \\
\hline$: t-13$ & 103 & cim & Stant & - & $=$ & repaired ball/serfect - had ecme span \\
\hline & & & & & & $825 / 1.000$ \\
\hline$u$ & $\frac{1 / 30}{1200}$ & $\frac{2 m}{189}$ & $\frac{O K}{0 n}$ & 4 & 10,800 & $3 n^{2}$ \\
\hline & 1230 & 286 & ok & 5 & & \\
\hline & 1300 & Jse & Or & & & \\
\hline & 1430 & $\cos$ & ok & 7 & & $34^{\circ}$ \\
\hline & $\frac{i 533}{i .630}$ & $\frac{c \sin }{c \sin }$ & $\frac{02}{02}$ & $\frac{8}{4}$ & $\left|\frac{21,600}{24} 200\right|$ & $7 x_{0} \beta_{1}$ \\
\hline 1.7 & $7: 00$ & 262 & $o k$ & & & downtor weck \\
\hline & espit2 & 10 & ak & 10 & 27,000 & $1.82 / 1.62$ \\
\hline & 0900 & $\operatorname{csm}$ & brikan if & vture & 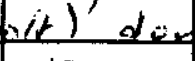 & 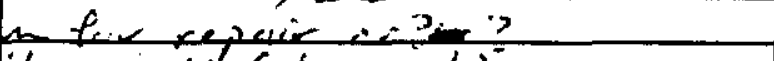 \\
\hline & $13 \times 0$ & $\mathrm{~cm}$ & replaced & $\frac{56 x}{10}$ & 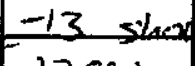 & der p. b.lt' (shop made) \\
\hline & 1500 & cim & & $\frac{10}{12}$ & 32400 & \\
\hline & 1600 & $\operatorname{cin}=$ & $0<$ & 13 & 35,100 & 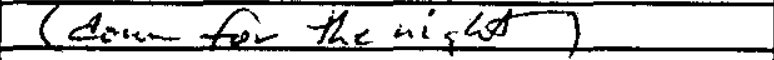 \\
\hline & and & 20 & 21 & $t$ & 7 & \\
\hline $7-18$ & $\frac{10700}{1000}$ & $\frac{\cos }{\cos }$ & cost & $\frac{ \pm}{14}$ & $\frac{\gamma}{37800}$ & \\
\hline & 2100 & $\operatorname{csin}$ & OK & 15 & 40,500 & $25^{20} \mathrm{C}$ \\
\hline & 1200 & $\frac{c m}{c s i n}$ & $\frac{\alpha}{g c}$ & $\frac{16}{17}$ & $\frac{4 \cdot 3 ; 200}{4500}$ & $\frac{27 C^{2}}{2900}$ \\
\hline & $1+0$ & $\operatorname{con}$ & oth & 18 & $69^{\prime} 600$ & $\frac{2.0}{25^{2} \mathrm{C}}$ \\
\hline & $\sqrt{200}$ & $\operatorname{csi}$ & ok & 19 & 51,300 & $.820 / 1.620$ \\
\hline & & & & & & 7erminats \\
\hline & & & & & & $c$ aki \\
\hline & - & & & & & \\
\hline & & & & & & \\
\hline & - & & & & . & - \\
\hline & & & & & & \\
\hline & & & & & & \\
\hline & & & & & & \\
\hline & & & & & & \\
\hline & & & & & & \\
\hline & & & & & & \\
\hline & & & & & & \\
\hline & & & & & & \\
\hline
\end{tabular}


Tesit \#3 (PNAL T.001)

$H N F-3526$ REV 3

PAGE C-4

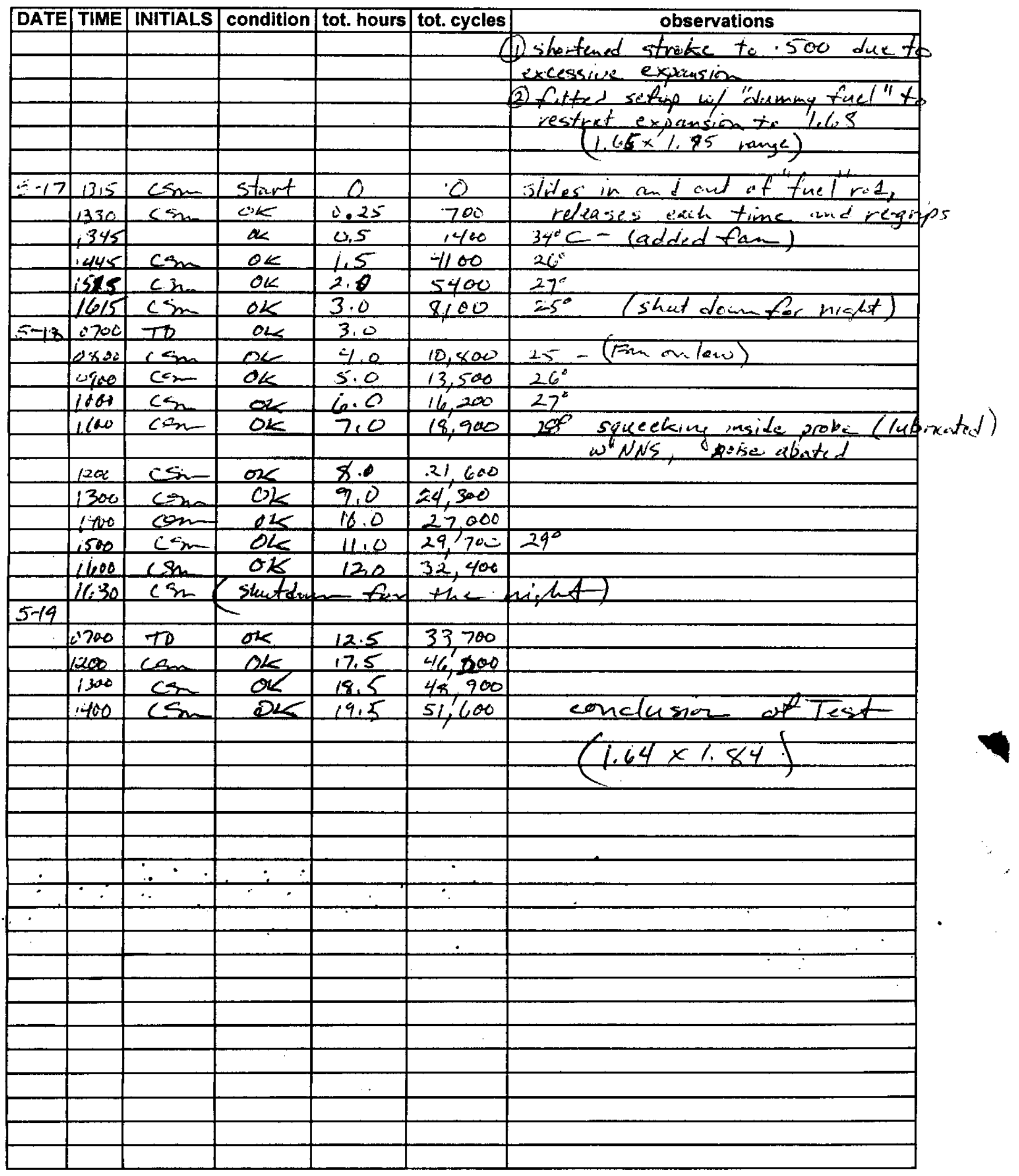




\section{Appendix D}

Design Verification Test Specification and Acceptance Test Specification 
SEE PREVIOUS REVISIONS FOR :

Design Verification Test Specification 


\section{FRS Manipulator Fuel Stinger Adjustment and Acceptance Test Procedure}

HNF-3526 Rev 3

Page 4012

Obiective:

This procedure is to be used to verify that each production stinger tool (each unit) is properly adjusted and fully functional prior to deployment. This procedure will be performed only after shop fabrication and quality inspection has been completed. This procedure is not intended to document fabrication quality or inspection results.

\section{Adiustment Procedure:}

Activate the stinger tool several times prior to recording collet OD. The tool adjustment will be rechecked after completion of the ATP to verify that adjustment is still set correctly. If readjustment is required, repeat ATP portion of this procedure.

1. Adjust or activate stinger tool so that the expanding collet collapses to its natural position (minimum outside diameter).

2. Measure collet outside diameter using dial caliper.

3. Record measurement: Measurement should be less than 1.64"

4. Place the $30 \mathrm{lbs}$ test element with an ID of 1.9 " on the table.

5. Place the test element with an I.D. of 1.64" into the go/no-go gage.

NOTE: For operator safety, exit the fenced area any time the manipulator system is active. The manipulator will be controlled remotely from the EOC. Test personnel will activate the local E-Stop before entering the fenced area and keep it depressed the entire time they are inside the fenced area. This effectively prevents the HPU from starting. Reset the E-Stop when exiting the fenced area.

6. Place stinger tool on the manipulator and activate stinger tool to full collet expansion.

7. Measure collet outside diameter using dial caliper.

8. Record measurement: Measurement should be equal to or greater than $1.9^{\prime \prime}$

\section{Acceptance Test Procedure:}

1. Use the manipulator to lift the 30 lbs test element with an ID of 1.9".

2. Set the 30 lbs test element with an ID of 1.9" back onto the table and release it.

3. Repeat steps 1 and 2 twelve times. Readjust tool as required and repeat series of twelve lifts.

4. Use the manipulator to pick up (clear of go/no-go gage) and reset the test element with an I.D. of 1.64" twelve times.

5. Place the $30 \mathrm{lbs}$ test element with an ID of 1.9" into a bucket of water on the mockup table.

6. Use the manipulator to lift the submerged 30 lbs test element with an ID of 1.9 " clear of bucket twelve times.

7. Use the manipulator to load the go/no-go gage with dummy outer fuel elements.

8. Load the dummy outer fuel elements into the mockup MCO fuel basket.

9. Repeat steps 7 and 8 until all the MCO basket slots have been filled.

10. Load 20 of the dummy inner elements into the mockup MCO fuel basket.

\section{Recheck Tool Adiustment}

1. Fully expand the collet and re-measure the outside diameter.

2. Record measurement:

3. Fully collapse the collet and re-measure the outside diameter

4. Record measurement: Measurement should be less than 1.64". 


\section{FRS Manipulator Fuel Stinger Adjustment and Acceptance Test Procedure}

HNF-3526 Rev 3

Page $202^{2}$

Acceptance Criteria and Data Sheet:

Date:

Tool Description (dwg\#, S/N, etc.):

Test Operator(s) (Name):

Test Director Acceptance:

1. Did the tool pick up the test element with an I.D. of 1.64" twelve consecutive times?

Yes / No Comments:

2. Did the tool pick up the $30 \mathrm{lb}$ test element with an ID of $1.9^{\prime \prime}$ twelve times?

Yes / No Comments:

3. Did the tool pick up the submerged $30 \mathrm{lb}$ test element with an ID of 1.9 " twelve times?

Yes / No Comments:

4. Was a basket fully loaded with no adjustments made to stinger?

Yes / No Comments:

5. Do all fasteners, adjustments, etc. appear to still be tight and the tool functioning normally? Yes / No Comments:

6. Were any operational or functional abnormalities identified during the test?

7. Does a post test inspection reveal any evidence of wear, damage or other abnormalities?

If the answers to all of the above questions $1-5$ are yes and $6 \& 7$ are no, then the tool is acceptable. The test director will sign above only if the tool was acceptable. 


\section{Appendix E}

\section{Design Verification Test Report}

(This section will be filled in at a later date.) 
Page F-0

\section{Appendix F}

Value Analysis

(See previous revision for attachments) 